Jurnal e-GiGi (eG), Volume 2, Nomor 2, Juli-Desember 2014

\title{
KEBUTUHAN PERAWATAN ORTODONSI BERDASARKAN INDEX OF ORTHODONTIC TREATMENT NEED PADA SISWA KELAS II DI SMP NEGERI 2 BITUNG
}

\author{
${ }^{1}$ Monica A. V. Rumampuk \\ ${ }^{2}$ P. S Anindita \\ ${ }^{2}$ Christy Mintjelungan \\ ${ }^{1}$ Kandidat Skripsi Program Studi Kedokteran Gigi Fakultas Kedokteran \\ Universitas Sam Ratulangi Manado \\ ${ }^{2}$ Program Studi Kedokteran Gigi Fakultas Kedokteran Universitas Sam Ratulangi Manado \\ Email: monchavalencia@yahoo.com
}

\begin{abstract}
Orthodontic treatment need increases with the number of cases of malocclusion as one of the major problems in Indonesia and an oral health problems are sufficiently large as dental caries and periodontal disease. Orthodontic treatment need in a population is described by one measure, namely Index of Orthodontic Treatment Need (IOTN). The purpose of this study was to determine the needs of orthodontic treatment in the second-grade students of Junior High School 2 Bitung based IOTN consisting of Aesthetic Component and Dental Health Component. It was a cross sectional study of descriptive obsevational, conducted in Junior High School 2 Bitung at December 2013. It research was used the total population of the second grade students of Junior High School 2 Bitung, amounting to 460 students. The results showed, orthodontic care needs based on the AC is 304 people $77 \%$ do not require nursing care or only mild, 74 people $19 \%$ of borderline and need care 184.5 really need treatment. While orthodontic treatment needs based DHC is $76 \%$ of 303 people do not require treatment or light treatment only, 63 people took care borderline $16 \%, 7.6 \%$ and 30 people really need treatment. Orthodontic treatment need by Index of Orthodontic Treatment Needs in second grade at Junior High School 2 Bitung mostly do not require or need minor maintenance in AC 77\% and DHC $76 \%$.
\end{abstract}

Keywords: Treatment Need, IOTN, Student Junior High School.

\begin{abstract}
Abstrak: Kebutuhan perawatan ortodonsi meningkat seiring bertambahnya jumlah kasus maloklusi sebagai salah satu permasalahan utama di Indonesia dan merupakan masalah kesehatan gigi dan mulut yang cukup besar setelah karies gigi dan penyakit periodontal. Kebutuhan perawatan ortodonsi pada suatu populasi digambarkan dengan salah satu alat ukur yaitu Index of Orthodontic Treatment Need (IOTN). Tujuan penelitian ini ialah untuk mengetahui kebutuhan perawatan ortodonsi pada siswasiswi kelas II SMP Negeri 2 Bitung berdasarkan IOTN yang terdiri dari Aesthetic Component (AC) dan Dental Health Component (DHC). Penelitian ini merupakan suatu penelitian Cross sectional yang bersifat deskriptif observasional, yang dilakukan di SMP Negeri 2 Bitung pada bulan Desember 2013. Pengambilan sampel pada penelitian ini menggunakan teknik total populasi pada siswa-siswi kelas II di SMP Negeri 2 Bitung yang berjumlah 460 orang. Hasil penelitian didapatkan, kebutuhan perawatan ortodonsi berdasarkan AC yaitu 304 orang $77 \%$ tidak membutuhkan perawatan atau hanya perawatan ringan, 74 orang $18,7 \%$ butuh perawatan borderline dan 18 orang 4,5 sangat butuh perawatan. Sedangkan kebutuhan perawatan ortodonsi berdasarkan DHC yaitu 303 orang 76,5\% tidak membutuhkan perawatan atau hanya perawatan ringan, 63 orang 15,9\% butuh perawatan borderline, dan 30 orang 7,6\% sangat butuh perawatan. Kebutuhan perawatan ortodonsi berdasarkan IOTN pada siswa kelas II di SMP Negeri 2 Bitung sebagian besar tidak membutuhkan atau butuh perawatan ringan pada AC 77\% dan DHC 76\%.
\end{abstract}

Kata kunci: Kebutuhan Perawatani, IOTN, Siswa SMP. 
Ilmu ortodonsi dalam bidang kedokteran gigi semakin berkembang dan semakin banyak orang ingin memperbaiki posisi gigi mereka yang tidak teratur. Kesadaran tentang penampilan fisik meningkat selama anak-anak mendekati remaja, maka masa remaja dianggap sebagai sebuah kelompok usia yang relevan untuk meneliti persepsi penampilan gigi pribadi. ${ }^{1}$ Pemakaian kawat gigi atau dalam istilah kedokteran gigi disebut perawatan ortodonsi merupakan salah satu jenis perawatan gigi yang banyak diminati anak remaja masa kini. ${ }^{2}$ Perawatan ortodonsi semakin banyak dilakukan untuk kebutuhan estetis yaitu memperbaiki penampilan seseorang dan meningkatkan kesehatan psikososial seseorang. Dengan perawatan ortodonsi letak gigi dan rahang yang abnormal diperbaiki sehingga fungsi geligi, estetik geligi dan wajah yang baik.

Penentuan kebutuhan perawatan ortodonsi pada anak remaja cukup penting karena tingkat kebutuhan bisa diidentifikasi dan keberhasilan perawatannya akan lebih baik. ${ }^{3}$

Kebutuhan perawatan ortodonsi pada suatu populasi digambarkan dengan salah satu alat ukur yaitu Index of Orthodontic Treatment Need (IOTN). ${ }^{4}$ Indeks tersebut telah diterima secara internasional, karena dinilai valid, dapat dipercaya, dan mudah digunakan. ${ }^{5}$ Index of Orthodontic Treatment Need terdiri dari 2 komponen, yaitu Aesthetic Component (AC) dan Dental Health Component (DHC). ${ }^{4}$ Aesthetic Component menilai persepsi seseorang tentang penampilan gigi-geligi pasien melalui sebuah skala fotograf, dimana terdapat 10-poin yang menunjukan tingkatan penampilan gigi-geligi yang secara estetik terlihat paling menarik dan 10 foto mewakili gigi-geligi yang secara estetik paling tidak menarik. Dental Health Component menilai beberapa jenis maloklusi seperti overjet, overbite, openbite, crossbite, crowding, erupsi palatal yang terhalang, anomali palatal dan bibir, serta hypodonsia. ${ }^{4}$

World Health Organization (WHO) pada tahun 1995 telah mengukur prevalensi kebutuhan perawatan ortodonsi di 10 negara industri, dimana kebutuhan perawatan ortodonsi berkisar 21-64\%. ${ }^{3}$ Penelitian mengenai kebutuhan akan perawatan ortodonsi telah dilakukan di banyak negara dimulai pada tahun 1950 oleh Massler dan Frankel. Penelitian di Skandinavia membandingkan susunan gigi pada manusia abad 20 dengan dengan susunan gigi pada era abad ke-16, dan hasilnya menunjukkan bahwa pada abad ke-20 prevalensi dan keparahan maloklusi kian meningkat dan membutuhkan perawatan ortodonsi.

Penelitian mengenai kebutuhan perawatan ortodonsi pada anak usia 13-14 tahun dengan menggunakan IOTN telah dipublikasi di Inggris pada tahun 1994, hasilnya ialah sepertiga dari anak usia 13-14 tahun membutuhkan perawatan ortodonsi. Penelitian sejenis juga telah dilakukan di Manado pada tahun 2010 tentang kebutuhan perawatan ortodonsi pada SMP Eben Heazer I usia 13-14 tahun oleh Musyulianti, dimana kebutuhan perawatan ortodonsi berkisar 328\%. ${ }^{6}$ Penelitian tentang kebutuhan perawatan ortodonsi berdasarkan IOTN juga ditemukan pada siswa SMA di kecamatan Malalayang Manado dilakukan pada tahun 2011 oleh Endang, dengan 5-17\% mem-

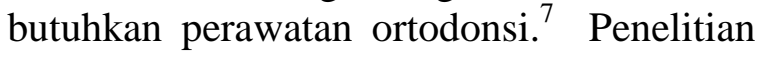
yang sama juga tentang kebutuhan perawatan ortodonsi yang dilakukan pada siswa Sekolah Menengah Pertama Katolik Theodorus Kota Kotamobagu pada tahun 2013 oleh Hansu, dengan membutuhkan perawatan ortodonsi $4-14 \%{ }^{8}$

\section{BAHAN DAN METODE}

Penelitian dilakukan di SMP Negeri 2 Bitung pada bulan Desember 2013. Sampel pada penelitian ini ialah siswa-siswi kelas 2 yang berjumlah 396 siswa. Metode pengambilan sampel yang digunakan dalam penelitian ini ialah total sampling.

Data primer berupa data jenis kelamin dan hasil pengukuran AC dan DHC berdasarkan IOTN yang dilakukan sendiri oleh peneliti. Data sekunder meliputi data jumlah siswa dan data sosial ekonomi orang tua siswa yang diperoleh dari sekolah.

Data disajikan dalam bentuk Tabel berdasarkan jenis kelamin, AC dan DHC, 
Rumampuk, Anindita, Mintjelungan; Kebutuhan Perawatan Ortodonsi...

kemudian dianalisis berdasarkan hasil persentase.

\section{HASIL PENELITIAN}

Karakteristik subjek penelitian berdasarkan jenis kelamin dapat dilihat pada Tabel 1.

Tabel 1. Distribusi subjek penelitian berdasarkan jenis kelamin

\begin{tabular}{lcc}
\hline Jeniskelamin & $\boldsymbol{n}$ & $\mathbf{( \% )}$ \\
\hline Laki-laki & 190 & 48 \\
Perempuan & 206 & 52 \\
Jumlah & 396 & 100 \\
\hline
\end{tabular}

Hasil penelitian berdasarkan AC dapat dikelompokan menurut kriteria tidak/sedikit butuh perawatan, butuh perawatan borderline, dan sangat butuh perawatan pada Tabel 2. Hasil penelitian berdasarkan DHC juga dapat dikelompokkan menurut kriteria tidak/ sedikit butuh perawatan, perawatan borderline, dan sangat butuh perawatan pada Tabel 3. Hasil pemeriksaan AC dapat di distribusikan berdasarkan jenis kelamin laki-laki dan perempuan pada Tabel 4. Hasil pemeriksaan DHC juga dapat dikelompokkan berdasarkan jenis kelamin pada Tabel 5.

Hasil penelitian dapat dibandingkan berdasarkan AC dan DHC pada Tabel 6.

Tabel 2. Distribusi berdasarkan AC pada subjek penelitian

\begin{tabular}{llll}
\hline Kebutuhan Perawatan Ortodonsi & \multicolumn{1}{c}{ AC } & \multicolumn{1}{c}{$n$} & (\%) \\
\hline Tidak butuh atau ringan & Nilai 1 & 26 & 6,6 \\
& Nilai 2 & 75 & 18,9 \\
& Nilai 3 & 120 & 30 \\
& Nilai 4 & 83 & 20,9 \\
\hline Borderline & Nilai 5 & 44 & 11,1 \\
& Nilai 6 & 27 & 6,8 \\
& Nilai 7 & 3 & 0,7 \\
\hline Sangat Butuh & Nilai 8 & 16 & 4 \\
& Nilai 9 & 2 & 1 \\
& Nilai 10 & 0 & 0 \\
\hline Total & 396 & 100 \\
\hline
\end{tabular}

Tabel 3. Distribusi berdasarkan DHC pada subjek penelitian

\begin{tabular}{lccc}
\hline Kebutuhan Perawatan Ortodonsi & DHC & $n$ & $(\%)$ \\
\hline Tidak butuh atau ringan & Nilai 1 & 175 & 44,1 \\
& Nilai 2 & 128 & 32,3 \\
\hline Borderline & Nilai 3 & 63 & 15,9 \\
\hline Sangat Butuh & Nilai 4 & 16 & 4,2 \\
& Nilai 5 & 14 & 3,5 \\
\hline Total & 396 & 100 \\
\hline
\end{tabular}

Tabel 4. Distribusi AC berdasarkan jenis kelamin

\begin{tabular}{|c|c|c|c|c|c|c|c|c|}
\hline \multirow{2}{*}{\multicolumn{2}{|c|}{ Kebutuhan Perawatan Ortodonsi AC }} & \multicolumn{3}{|c|}{ Laki-laki } & \multicolumn{3}{|c|}{ Perempuan } & \multirow[t]{2}{*}{ Total } \\
\hline & & $n$ & (\%) & $n$ & (\%) & $n$ & (\%) & \\
\hline \multirow[t]{4}{*}{ Tidak butuh atau ringan } & Nilai 1 & 13 & 3,2 & 13 & 3,3 & 26 & 6,7 & \\
\hline & Nilai 2 & 29 & 7,3 & 46 & 11,6 & 75 & 18,9 & \\
\hline & Nilai 3 & 59 & 14,9 & 61 & 15,4 & 120 & 30,3 & \\
\hline & Nilai 4 & 52 & 13,1 & 31 & 7,8 & 83 & 20,9 & \\
\hline \multirow[t]{3}{*}{ Borderline } & Nilai 5 & 17 & 4,2 & 27 & 6,8 & 44 & 11,1 & \\
\hline & Nilai 6 & 12 & 3,4 & 15 & 3,8 & 27 & 6,9 & \\
\hline & Nilai 7 & 3 & 0,5 & 1 & 0,3 & 3 & 0,7 & \\
\hline \multirow[t]{3}{*}{ Sangat butuh } & Nilai 8 & 5 & 1,2 & 11 & 2,7 & 16 & 4 & \\
\hline & Nilai 9 & 1 & 0,2 & 1 & 0,3 & 2 & 0,5 & \\
\hline & Nilai 10 & 0 & 0 & 0 & 0 & 0 & 0 & \\
\hline Total & & 190 & 48 & 206 & 52 & 396 & 100 & \\
\hline
\end{tabular}


Tabel 5. Distribusi DHC berdasarkan jenis kelamin

\begin{tabular}{lcccccccc}
\hline Kebutuhan Perawatan Ortodonsi & DHC & \multicolumn{3}{c}{ Laki-laki } & \multicolumn{3}{c}{ Perempuan } & Total \\
& & $n$ & $(\%)$ & $n$ & $(\%)$ & $n$ & $(\%)$ & \\
\hline Tidak butuh atau ringan & Nilai 1 & 86 & 21,7 & 89 & 22,5 & 175 & 44,2 \\
& Nilai 2 & 67 & 16,9 & 61 & 15,4 & 128 & 32,4 \\
\hline Borderline & Nilai 3 & 32 & 8 & 31 & 7,8 & 63 & 15,9 \\
\hline Sangat butuh & Nilai 4 & 6 & 1,6 & 10 & 2,5 & 16 & 4 \\
& Nilai 5 & 4 & 1 & 10 & 2,5 & 14 & 3,5 \\
\hline Total & \multicolumn{195}{c}{199,2} & 201 & 50,7 & 396 & 100 \\
\hline
\end{tabular}

Tabel 6. Distribusi AC terhadap DHC

\begin{tabular}{|c|c|c|c|}
\hline IOTN & $\begin{array}{c}\text { Tidak atau sedikit } \\
\text { butuh perawatan } \\
\text { n } \%\end{array}$ & $\begin{array}{c}\text { Borderline } \\
\text { n \% }\end{array}$ & $\begin{array}{l}\text { Sangat butuh } \\
\text { perawatan } \\
\text { n } \%\end{array}$ \\
\hline $\mathrm{AC}$ & 30476,7 & $74 \quad 18,7$ & $18 \quad 4,5$ \\
\hline DHC & 30376,5 & 6315,9 & 7,6 \\
\hline
\end{tabular}

\section{BAHASAN}

Berdasarkan hasil pemeriksaan AC pada Tabel 2, menunjukkan bahwa dari segi penampilan atau AC sebagian besar tidak membutuhkan perawatan atau hanya perawatan ringan yaitu sebanyak 304 orang (76,74\%). Nilai 3 merupakan jumlah terbanyak dalam kelompok yang tidak membutuhkan perawatan atan hanya perawatan ringan ini yaitu 120 orang (30,30\%). Pada perawatan borderline, nilai 5 merupakan jumlah terbanyak yaitu 44 orang $(11,11 \%)$.

Siswa yang tidak atau sedikit membutuhkan perawatan merupakan kelompok yang mendominasi. Hal tersebut dapat disebabkan oleh status ekonomi dari orang tua siswa yang secara umum berasal dari keluarga dengan sosial ekonomi mampu dan memiliki pengetahuan yang cukup tentang kesehatan gigi dan mulut. Latar belakang status ekonomi mampu dan pendidikan orang tua yang tinggi juga memengaruhi kebutuhan akan perawatan ortodonsi yang lebih rendah. Kesadaran mereka untuk melakukan kunjungan ke dokter gigi dalam hal perawatan lebih tinggi dikarenakan sosial ekonomi yang menunjang. Sebagian besar pekerjaan orang tua siswa ialah Pegawai Negeri Sipil (PNS) dengan presentase $50 \%$ sedangkan nelayan dan buruh $10 \%$, wiraswasta $23 \%$, tentara atau polisi $17 \%$. Hal tersebut didukung dengan penelitian Mandal yang menemukan bahwa status ekonomi memengaruhi kebutuhan perawatan ortodonsi dan penelitian pada 483 anak oleh Guray menunjukkan pada subjek dengan status ekonomi yang rendah (72,26\%) membutuhkan perawatan ortodonsi dan $(27,74 \%)$ tidak butuh perawatan ortodonsi. ${ }^{2}$

Berdasarkan data hasil penilaian nilai AC 3 merupakan nilai terbanyak pada penelitian ini yaitu dengan jumlah 120 orang (30,30\%). Foto yang diberi nilai 3 terlihat openbite posterior merupakan keadaan adanya ruangan oklusal atau insisal dari gigi saat rahang atas dan rahang bawah dalam keadaan oklusi sentrik pada regio premolar dan molar.

Penilaian DHC pada tabel 3, menunjukkan bahwa dari segi kesehatan gigi atau DHC sebagian besar tidak membutuhkan perawatan atau hanya perawatan ringan yaitu sebanyak 303 orang (76,51\%). Nilai 1 terbanyak dalam kelompok yang tidak membutuhkan perawatan ini yaitu 175 orang (44,19\%). Kelompok yang membutuhkan perawatan borderline menduduki peringkat kedua yaitu 63 orang (15,90\%). Kelompok yang sangat butuh perawatan merupakan jumlah terkecil dan yang terbanyak dari kelompok ini yaitu 
nilai 4 dengan jumlah 16 orang (4,04\%). Dibandingkan dengan hasil AC yang merupakan kelompok terbanyak ialah tidak membutuhkan perawatan atau perawatan ringan dengan hasil DHC. kelompok yang paling terkecil yaitu sangat membutuhkan perawatan. Jumlah kecil pada kelompok yang sangat membutuhkan perawatan merupakan angka yang cukup bagus dikarenakan hanya sedikit siswa yang didapati dengan masalah ortodonsi yang berat. Kelompok yang sangat butuh perawatan merupakan jumlah terkecil dan yang terbanyak dari kelompok ini yaitu nilai 4 dengan jumlah 16 orang (4,04\%). Dalam kelompok ini terdapat subjek yang memiliki peningkatan overjet $>6 \mathrm{~mm}$ tetapi $\leq 9 \mathrm{~mm}$, cross bite anterior atau prosterior dengan diskrepansi $>2 \mathrm{~mm}$, open bite anterior atau lateral yang parah $>4 \mathrm{~mm}$, persistensi gigi susu dan kelainan bibir sumbing atau cacat pada palatal.

Berdasarkan jenis kelamin, hasil total pengukuran DHC perbandingan laki-laki dan perempuan yaitu 190 siswa (48\%) dan 201 siswa (52\%). Hasil yang sama juga ditunjukkan oleh Hansu pada penelitian di SMP Katolik Theodorus Kotamobagu, dimana masing-masing dengan jumlah total 60 siswa (42\%) laki-laki dan 83 siswa (58\%) dalam pengukuran AC dan DHC. ${ }^{8}$

Berdasarkan dari jenis kelamin, penelitian ini memperlihatkan bahwa hasil pemeriksaan dengan pengukuran AC dan DHC memiliki perbedaan yang hampir sama nilainya antara laki-laki dan perempuan namun keduanya sama-sama didominasi oleh perempuan. Agusni pada penelitiannya di Surabaya menemukan bahwa anak perempuan lebih memiliki kebutuhan untuk perawatan ortodonsi. ${ }^{2}$ Pada penelitian tersebut terlihat kebutuhan akan perawatan ortodonsi pada anak perempuan sedikit lebih tinggi dibanding anak laki-laki karena perempuan lebih memerhatikan estetik disbanding laki-laki.

Penelitian yang dilakukan pada siswa kelas II SMP Negeri 2 Bitung dapa dilihat pada tabel 6, bahwa nilai AC dan DHC memiliki kesamaan dengan kelompok yang tidak/sedikit membutuhkan perawatan merupakan kelompok terbanyak dengan AC 304 orang (77\%) dan DHC 303 orang (76\%), sedangkan kelompok yang membutuhkan perawatan borderline dengan AC 74 orang (19\%) dan DHC 63 orang (16\%) dan yang paling sedikit kelompok yang sangat membutuhkan perawatan dengan AC 18 orang (5\%) dan DHC 30 orang (8\%). Untuk hasil kelompok borderline memiliki perbedaan dimana AC yang terbanyak dari DHC dan sebaliknya untuk kelompok yang sangat membutuhkan perawatan, hasil DHC yang lebih banyak dari AC.

Banyak pendapat mengenai hasil AC yang kurang valid karena pemeriksaan AC hanya menilai secara subjektif dengan melihat sisi penampilan dari gigi pasien, dibandingkan dengan pemerikasaan DHC yang secara objektif dengan melakukan pemeriksaan dan pengukuran keadaan gigi dan mulut. Dengan demikian hasil penelitian menunjukkan bahwa mereka yang berdasarkan hasil AC penampilan gigigeliginya terlihat baik, namun berdasarkan hasil DHC mereka membutuhkan perawatan. $^{8}$

\section{SIMPULAN}

Berdasarkan Aesthetic Component (AC) pada siswa kelas II di SMP Negeri 2 Bitung sebagian besar tidak membutuhkan atau butuh perawatan ringan.

Berdasarkan Dental Health Component (DHC) pada siswa kelas II di SMP Negeri 2 Bitung sebagian besar tidak membutuhkan atau butuh perawatan ringan.

\section{DAFTAR PUSTAKA}

1. Foster TD. Buku Ajar Ortodonsia (Edisi Ketiga). Yuwono L, Translator. Jakarta: Buku Kedokteran EGC, 2000; hal.29-166.

2. Rahardjo P. Orthodonti dasar. Surabaya: Airlangga University Press, 2009; hal.2-3, 60.

3. Dewi O. Analisis hubungan maloklusi dengan kualitas hidup pada remaja SMU kota Medan tahun 2007. Tesis. Medan: Universitas Sumatera Utara. 2009;14(2):115-9. 
4. Brook PH, Shaw WC. The development of an index of orthodontic treatment priority. Eur J Orthod 2009;11(3):309-320.

5. Dika D. Hamid T. Sylvia M. Penggunaan index of orthodontic treatment need (iotn) sebagai evaluasi hasil perawatan dengan piranti lepasan. Ortho Dent J 2011;1:12-17.

6. Musyulianti. Kebutuhan perawatan ortodonsi pada SMP Eben Heazer I Manado [Skripsi]. Manado: Program Studi
Kedokteran Gigi Fakultas Kedokteran Universitas Sam Ratulangi; 2010:36.

7. Endang, S. Kebutuhan perawatan ortodonsi pada SMA kecamatan Malalayang Manado [Skripsi]. Manado: Program Studi Kedokteran Gigi Fakultas Kedokteran Universitas Sam Ratulangi; 2011:34.

8. Hansu C. Kebutuhan perawatan ortodonsi berdasarkan index of orthodontic treatment need di SMP Katolik Theodorus Kotamobagu. Jurnal e-GiGi (eG); 1(2):September 2013:99-104. 